\title{
SPECIAL ASPECTS OF PERSONAL REHABILITATIVE RESOURCES OF ACTUAL AND DEMOBILIZED MILITARY SERVICE MEMBERS
}

\author{
Olesia Prokofieva ${ }^{1}$ Inna Koshova ${ }^{2}$, Olga Prokofieva ${ }^{3}$ \\ ${ }^{1} \mathrm{PhD}$. (psychological sciences), Associate Professor, associate professor of the \\ Department of Psychology, Bogdan Khmelnytsky State Pedagogical University in Melitopol, \\ Melitopol (Ukraine) \\ ORCID ID: https://orcid.org/0000-0002-6542-239X \\ ReseacherID: C-8660-2018 \\ ${ }^{2} \mathrm{PhD}$. (psychological sciences), Associate Professor, associate professor of the \\ Department of General and Applied Psychology, Mykola Gogol State University in Nizhyn, \\ Nizhyn (Ukraine) \\ ${ }^{3}$ Senior lecturer of the Department of Anatomy and Physiology of Human and Animals, \\ Bogdan Khmelnytsky State Pedagogical University in Melitopol, Melitopol (Ukraine)
}

ORCID ID: https://orcid.org/0000-0002-6096-2653

ReseacherID: D-4572-2018

UDC: 1599: 305-055.2: 355.422 (477)

\begin{abstract}
The article presents the results of the empirical study on personal rehabilitative resources of actual and demobilized military service members (coping strategies, strategies of resistance, psychological hardiness). The combat experience of actual and demobilized military service members leads to severe personality traumas, appeared symptoms of post-traumatic stress disorders, severe tension of their adaptive potential. The situation can be controlled with active problem- and emotionally-focused coping strategies in order to transform the situation, rather than to escape it. In particular, these are the strategies involving positive re-appraisal, plannful problem solving, and increased self-control. Several gender differences in the use of copings were identified. The study shows that the position focused on effective self-development in the most sustainable. Along with the severe symptoms of maladaptation, the combatants consider also their experience as one that shows the value of life and self-enrichment.
\end{abstract}

Key words: combat stress, combat psychological trauma, post-traumatic growth, coping strategies, psychological hardiness, personal rehabilitative resources, actual service members, demobilized service members, veterans.

Address for correspondence, e-mail: editpsychas@gmail.com Copyright: C Olesia Prokofieva, Inna Koshova, Olga Prokofieva

This is an Open Access journal, all articles are distributed under the terms of the Creative Commons AttributionNonCommercial-ShareAlike 4.0 International (CC BY-NC-SA 4.0) License (http://creativecommons.org/licenses/by-nc$\mathrm{sa} / 4.0 /$ ), allowing third parties to copy and redistribute the material in any medium or format and to remix, transform, and build upon the material, provided the original work is properly cited and states its license. 
Problem definition and its relationship with important scientific and practical tasks

Modern Ukrainian society is in a difficult crisis, covering all spheres of public life and profoundly affecting every individual. The impact of war stressors is felt by the entire population of Ukraine. Psychological traumatic factors lead to changes in the structure of a personality, breaking the perception of life continuity, changed individual cognitive structures; they destroy an individual's basic idea on the world and own personality, reduce an individual's ability to predict the future, build intentions, and deform an individual's psyche. Symptoms of psychological traumatization (post-traumatic stress disorders, depression, disorientation, loss of life meaning) are characteristic to some degree (immediately or in delay) for a large part of war participants. Therefore, it is urgent in the current Ukrainian realities to restore the resources of personal psychological hardiness, to explore new opportunities for personal rehabilitation, in particular for actual and demobilized military service members. The difficulties of returning to a peaceful life is repeatedly emphasized by both Ukrainian and foreign psychologists (R. Abdurakhmanov, A. Karayani, Z. Kisarchuk, O. Kokun, V. Kolodzin, P. Levin, L. Litvinenko, O. Misko, M. Reshetnikov, O. Romanchuk, V. Shamrei, E. Snedkov, V. Shevchenko, N. Tarabrina, T. Titarenko) who note that the return of military service members to a peaceful life requires social participation, in particular, psychological assistance to demobilized service members in the forms of psychological support, rehabilitation, adaptation, abilitation.

The problems of psychological rehabilitation are considered within the framework of military- psychological (A. Karayani, B. Kolodzin, I. Koshova, T. Vinnicka, V. Yagupov); medical (Y. Alexandrovsky, M. Ivanov, B. Karvasarsky), general psychological (K. AbulkhanovSlavskaya, L. Kitaev-Smyk, N. Tarabrina) and socioal-psychological (A. Antsupov, V. Frankl, J. Kelly, S. Maksimenko, V. Myasishchev, K. Rogers) approaches, which propose is the integrated use of medical, social, psychological, educational and professional rehabilitative measures and description of common principles of their organization.

In the modern conditions, rehabilitation (providing of rehabilitative services) is complicated by a lot of circumstances: the continued military operation, the crisis of society, nonadaptive strategies used by service members, ambiguous attitudes to psychological assistance in society, which complicates seeking for psychological assistance by service members; mentality that encourages martyrdom and patience; believes that most people can overcome difficult circumstances on their own. However, the large-scale traumatization forces to look for ways to facilitate rehabilitation, one of which is the reliance on personal rehabilitative resources. The effectiveness of psychological rehabilitation depends heavily on the used inner personal potential, the focus not only on the changed socio-and-psychological as- 
pects of an individual's life, but also the preserved skills, available psychological resources, experience and newly revealed resources.

The analysis of recent research and publications

A combat stress as a result of combat task execution is a multilevel process of human adaptation at the combat conditions, which strains the mechanisms of reactive self-regulation and secures specific adaptive psychophysiological changes (Karayani, 2003; Karayani, 2014), causes physiological and emotional reactions. Focused stress mood contributes to survival, but in the case of its severe intensity and duration, a combat stress reaction occurs. It is expected that combat stress can generate adaptive stress reactions, facilitated by effective leadership, adequate relationships between service members: mutual trust, cohesion, fighting spirit of a military unit based on identification and community membership (Shamrei, 2015). Adaptation to combat conditions can be quick, as a set of reactions to adapt to unusual stimuli. But long-term adaptation is accompanied by dramatic mental and personal changes of combatants, developed in order to survive in extreme war conditions (Karayani, 2003; Karayani, 2014). Non-adaptive stress reactions that are pathological or manifested as deviant, criminal, suicidal, and homicidal behavior are also possible (Shamrei, 2015). Pathological reactions are similar to the symptoms of mental disorders, but have transient and polymorphic manifestations (Shamrej, 2015).
Adaptation to the war stressors ("combat stress") is a normal adaptive reaction, but strong, long-lasting adverse effects that exceed an individual's adaptive potential (psychological resource) lead to a psychological trauma (combat psychological trauma). A response to a traumatic event can be without adaptation disorders, but also may have signs of pathological psychic adaptation and adaptation disorders. According to E. Snedkov, in the situation of permanent hostilities, mental disorders develops approximately during 8.4 months at the combat zone, but their high initial intensity appears only during 1.8 months (Snedkov., 1997). Post-traumatic stress disorders (PTSD) is the best studied long-term consequence of trauma, including mental health (Snedkov., 1997).

According to O. Kokun, N. Agayev, N. Lozinska the most frequent stressful combat factor for the ATO combatants (according to the Scale of Combat Experience Intensity) is the frequency of observed deaths or injuries during military actions. Blockade by the enemy forces and the risk of death, injuries and other very dangerous situations have an expressed stressful effect. It was established that the frequency of being under enemy firing and the losses of a combat unit during the fighting practically do not correlate with PTSD symptoms. In the modern conditions, the most stressful are the following factors: fear of one's own death or injury, stressors of moral and ethical character, long-lasting fatigue, problems in family life, smells of gases, corpses etc. 
Strong stressors are the physical liquidation of enemy combatants (especially for the first time), the inability to change life conditions; corpses, blood, explosions, buzzing, roaring, crashing, shooting, the destruction of buildings, machinery, structures, landscapes; intense interpersonal conflicts (Kokun, Agayev, Lozinska, 2018).

According to M. Reshetnikov, S. Chermyanin, V. Korzunin, the military service members have certain difficulties of social and psychological re-adaptation to peaceful life, which are expressed in the higher proneness to conflicts, lowered professional activity, dissatisfaction with intra-group contacts (Reshetnikov, Chermyanin., Korzunin, 2005). These psychological features are long-lasting and do not change significantly even 3 months after the combat cessation. The combatants have increased emotional lability, anxiety, neuro-and-psychic tension. These states are associated with their focus on own experiences, increased attention to external and internal conflicts, and reduced contacts within own reference group. During adaptation, hypochondriacal and psychasthenic reactions are often manifested, combined with the tendency to impulsive discharges of internal tension (Reshetnikov, Chermyanin., Korzunin, 2005; Syropyatov, 2013). The existing internal (personal) and external social resources support better adaptability. These internal (personal) and external (social) resources give a person psychological resistance to stress and social and psychological adaptation can proceed without significant psychopathological disorders. However, the states estimated as an adaptation disorder and maladaptation are, in fact, a manifestation of good adaptation to an extreme situation. Therefore, it is worth talking not about the violations of adaptation, but about the need to readapt the combatants to new (peaceful) conditions. Their social perception as "sick" people and negative assessment of their experience significantly complicate re-adaptation.

A long-time stay in combat conditions and adaptation to peaceful life conditions demand preservation and restoration of mental adaptation reserves. Analysis of scientific sources shows that the researchers are increasingly interested not only in manifestations of stressful experiences, but they also explore the psychological mechanisms of stress overcoming. For example, changes in motivation, the features of cognitive functions responsible for efficient information processing, the role of emotional regulators of behavior, individual methods for overcoming of difficulties (V. Bodrov, N. Vodopianova, L. Kitaev-Smyk and others). The scientific works repeatedly emphasize the importance of personal motivation, the mood supporting problem solving; they analyze the nature and scope of the problems and environmental conditions necessary for choosing adequate and available resources for problem solution.

One of the possible responses to traumatic stress is deep personal transformation, occurring in parallel with the person's attempts to adapt to difficult life circumstances against the back- 
ground of psychological distress (M. Zelenov, A. Zelenin, V. Klimchuk, M. Magomed-Eminov, R. Tedeschi, O. Tolkachyova, L. Calhoun). M. Magomed-Eminov believes that a person under a stressful event has three paths, three life paths: life, life, and life. The trajectory of one's life path is not only negative (stress syndrome, etc.), but also positive (adaptation, integration) and creative (growth and development) (Magomed-Eminov, 2009). R. Tedeschi and L. Calhoun, co-founders of the concept of post-traumatic growth, understand this phenomenon an experience of deep personal transformation rather than a return to the previous level of functioning. These changes are not a direct consequence of a traumatic event and an existing goal, but they occur together with a person's attempts to adapt to difficult life circumstances. Personal growth takes place against a background of high levels of psychological distress and may even be an unexpected outcome for the person (Tedeschi, Calhoun, 2004).

The purpose of the article is to find out the peculiarities of rehabilitative resources of actual and demobilized military service members, to estimate (at the first stage of the study) the nature of their combat experience, levels of their traumatization and to study personal resources for control over stress situations, which is important for determination of the personality component of rehabilitative potential.

\section{Methods and techniques}

The research used the following standard- ized questionnaires: "Scale of combat experience intensity", Mississippi Scale (assessment of posttraumatic reactions (military version), "Ways of Coping Questionnaire" of R. Lazarus and S. Folkman, Posttraumatic Growth Inventory of R.G. Tedeschi and L.G. Calhoun, Maddi's Personality Hardiness Scale. Statistical data processing was performed along with qualitative analysis and interpretation of the obtained data. The Pearson linear correlation method and MannWhitney U-test were used. Data processing was performed using the statistical data processing in Excel.

The main material study with substantiation of scientific results

The research was performed on the basis of 56 Separate Motor Infantry Brigade, 23 Motor Infantry Battalion, 57 Separate Motor Infantry Brigade, 1 Motor Infantry Battalion, 92 Separate Mechanized Brigade of the Armed Forces of Ukraine in 2019. The number of respondents was 27 combatants (17 men and 10 women). The average age of men was 32.5 years (from 23 to 51 years). The average age of women (23 to 49 years) was 33.6 years. The duration of their stay in the combat zone was from 1 month to 2.5 years. The majority (89\%) of them returned to military service after being in the combat zone. $11 \%$ of them were demobilized. $51 \%$ of the respondents were in the zone of enemy firing, 29\% were there over 6 months. $92.5 \%$ were not surrounded by the enemy, but $7.5 \%$ reported it. 
There are no losses in the units of $51 \%$ of the respondents, but $40 \%$ report losses up to $25 \%$ of their units. $33 \%$ of the respondents observed wounds and deaths during the fighting, and $43 \%$ themselves were at risk of being killed or injured (bullets, shells, weapons), were ambushed and experienced other very dangerous situations. Therefore, their combat experience is quite diverse. Most often $(31.7 \%)$ they reported being under direct enemy fire (firearms, artillery, rockets or mortars) and shelling with sniper fire (31.5\%). 22\% had experience at a front-line observation post. $11 \%$ saw mine explosions or traps being at the sentry or at the place of service or were ambushed, $7 \%$ were injured, $3 \%$ were injured and now have disabilities as a result of combat. In general, the combat experience of the examinees is polygenic.

The evaluated intensity of the combat experiences revealed the heterogeneity of the studied group and allowed us to see the polyvalence of combat impacts.

By analyzing the data obtained with the Mississippi Scale for Post-Traumatic Response Assessment, we recorded the PTSD manifestations at the examinees. The scale indicators of $89 \%$ of the examinees exceed 112 points, which correspond to existing PTSD. For comparison, N. Tarabrina, V. Agarkov, Y. Byhovec diagnosed indicators from 77 to 107 points at veterans of the USSR-Afghanistan war (Tarabrina, Agarkov, Byhovec, 2007). No one of the examinees showed good adaption. In general, this indicates a significant impact of combat trauma on the examinees; those of them who stay in the combat zone continue to experience strong stress. It is also noteworthy that the average score on the scale for the examined women $(\mathrm{m}=132.6$ points $)$ exceeds the average score for the men $(\mathrm{m}=116.9)$.

The data obtained can be explained by the long-term action of the war factors. According to V. Shamrei, unlike ordinary people appeared at a disaster area for a short time, the military service members are in danger all the time (Shamrei, 2015). During the war and combat actions, combatants stay permanently under the conditions of chronic danger for their health and life, situations when they must kill other people. The motivation for combat activity is complex and contradictory, and the broad social motives are not presented in detail, so it is a base for intrapersonal conflicts that intensifies stress.

One of our research objectives was to study personal resources, which is important for determination of the personality component of rehabilitative potential. Resistance to stress is studied mainly in the context of coping strategies. Coping or coping strategies are active, mostly conscious, efforts of a person; such strategies are launched in a threatening situation and are aimed at mastering of this difficult situation and problem solving. Coping behavior tales place when a person is in a crisis, is experiencing life difficulties and should be adapted to such situation. Ef- 
fective control includes attempts to solve a prob- (“confrontive copimg”), 2 (“distancing”) and 6 lem on their own, seeking for social support, ("escape-avoidance") is a positive indicator bechanging of own attitudes to the situation, objec- cause, as N. Vodopyanova points out tive assessing of the situation, self-control and (Vodopyanova, 2009), successful socioaccepted responsibility. The studied coping strategies of the combatants as their resources for coping with stress situations are presented in Table 1.

psychological adaptation is possible.

Planful problem solving means the pur-

Table 1.

\section{Mastering Strategies ("Ways of Coping Questionnaire” of R. Lazarus and S. Folkman)} [compiled by the authors]

\begin{tabular}{|l|l|l|l|l|l|l|l|l|}
\hline Strategies & $\begin{array}{l}\text { Con- } \\
\text { frontive } \\
\text { Groping }\end{array}$ & $\begin{array}{l}\text { Distanc- } \\
\text { ing }\end{array}$ & $\begin{array}{l}\text { Self- } \\
\text { control- } \\
\text { ling }\end{array}$ & $\begin{array}{l}\text { Seeking } \\
\text { Social } \\
\text { Support }\end{array}$ & $\begin{array}{l}\text { Accepting } \\
\text { Respons-- } \\
\text { bility }\end{array}$ & $\begin{array}{l}\text { Escape- } \\
\text { Avoid- } \\
\text { ance }\end{array}$ & $\begin{array}{l}\text { Planful } \\
\text { Problem- } \\
\text { solving } \\
\text { planning }\end{array}$ & $\begin{array}{l}\text { Positive } \\
\text { Re- } \\
\text { appraisal }\end{array}$ \\
\hline Men & 48,3 & 48,3 & 59,5 & 56,7 & 53,3 & 46,25 & 68,9 & 59,0 \\
\hline Women & 44,4 & 48,8 & 60,4 & 63,3 & 50 & 35,4 & 78,3 & 65,7 \\
\hline Total & 47,1 & 48,3 & 60,5 & 58,3 & 52,7 & 43,3 & 71,7 & 60,9 \\
\hline
\end{tabular}

The ATO combatants tend to choose such strategies as "planful problem-solving" (71.7\%), "positive re-appraisal" (60.9\%) and "selfcontrolling" (60.5\%). The most stressful was the problem-oriented coping of "planful problemsolving", combined with two emotionallyoriented ones ("positive re-appraisal" and "selfcontrolling"), which, as parts of the total coping efforts, contribute to one another and together work on adaptation. Their levels are above average. It is also noteworthy that there is a general high level of stress, except for "escapeavoidance" strategy (43.3\%).

The obtained data show that the examinees' adaptive potential is on the border or close to the expressed maladaptation state (reaches 13 points). However, the higher results for 3 ("selfcontrolling"), 7 ("planful problem-solving") and 8 ("positive re-appraisal") scales over 1 poseful analysis of a situation to find possible behavior, planning own actions with taking into account available resources and own experience; such approach facilitates adaptation and allows a person to feel free and relaxed. Those who chose this strategy have positive attitudes to themselves as well as to others, because they focus on overcoming of difficulties, are able to optimally allocate their emotional resources. It should be noted that this coping is typical for almost all participants of our study. This strategy is significantly expressed at $22 \%$ of them and averagely expressed at $74 \%$.

The positive re-appraisal of a problematic situation involves attempts to reconsider, to perceive the problem as a factor of personal growth, to philosophically understand the problem situation, to include it into a wider context of selfdevelopment. Re-appraisal reduces negative emo- 
tions or turns them into positive emotions, facilitates adaptation and brings emotional comfort. However, overcoming of a problem with it reconsideration may prevent effective solution of the problem. Sometimes, instead of acting, an individual refuses to deal with the problem and denies to it. Those participants of our study who use this coping manage to maintain a balance without running away from problems in the world of philosophies without use of escape-avoidance coping.

The escape-avoidance coping is characterized by low stress. But such approach delays and complicates adaptation. This strategy is inappropriate because it involves attempts to overcome negative experiences through denial of the problem, fantasizing, unjustified expectations, distraction, and evasion. The corresponding behavior is characterized by passivity, impatience, irritation, overeating, and alcohol or drug abuse in order to reduce emotional stress. However, L. Vasserman points out that in some situations this strategy can be useful, first of all, in acute, short-term stressful situations, while impulsive and too cautious actions can complicate social and psychological adaptation (Vasserman, 2009). Hastiness and recklessness prevent a person from objective assessing of a current situation and choosing of the best way of actions, and excessive caution makes a person anxious, uncertain, and timid.

The "self-controlling" copying is used enough often; it means overcoming of negative experiences by purposeful suppression and restraint of emotions, minimizing of their influence on perception of the situation and choosing of behavior, high control over behavior and desire for self-control. Women's tendency to do this coping is better balanced by seeking social support; such approach is not typical of men.

The T-score reduced data comparison with the data obtained by M. Novozhilova, in her study of military service members having the clinically verified diagnosis of F43.2 on ICD-10 (International Classification of Diseases) (Adaptation Disorder) aged from 24 to 51 years, revealed several differences (by Vasserman, 2009). The coping stress of our study participants does not reach the level of the service members having diagnosed adaptation disorders for the scales of 1, 2, 4, 5, 6 ("confronting coping", "distancing", "seeking social support", “escapeavoidance"), but exceeds this sample stress indicators for self-controlling copying, planful problem-solving, and positive re-appraisal (scales 3, 7, 8). According to N. Vodopyanova, this indicates positive tendencies of adaptation (Vodopyanova, 2009) (Table 2).

R. Lazarus and S. Folkman understand stress control as dynamic, behavioral and cognitive, constantly changing efforts to control external and internal demands that are compared with an individual's resources (by Kryukova, Kuftyak, 2007). This subjective process governs individual tendencies of behavior in stressful situations. 
Table 2.

Comparison of the data on prevalent forms of stress management (("Ways of Coping” of $R$. Lazarus and S. Folkman) [compiled by the authors]

\begin{tabular}{|l|l|l|}
\hline \multicolumn{1}{|c|}{ Strategies of control } & $\begin{array}{c}\text { ATO } \\
\text { combat- } \\
\text { ants }\end{array}$ & \multicolumn{1}{|c|}{ Military service members with the diagnosed adaptation disorders } \\
(data by N. Vodopyanova)
\end{tabular}

Since this model imply that psychological adaptation is a result of a person's interactions with a situation, and combat activities are, undoubtedly, a really stressful situation that causes similar patterns of behavior, it is possible to determine the general trends characteristic for the studies group and gender peculiarities of response to this situation.

The women-ATO combatants more often than men tend to turn to the following copying strategies: planful problem solving (average score for women is 78.3 and 68.9 for men), positive reappraisal (65.7 for women and 59 for men). Women seek also more often for social support (63.8 points). Men tend to rely more on selfcontrol (59.5), although social support is also significant for them.

Psychological hardiness is a component of a personal potential that supports effective selfdevelopment in stressful situations and extreme life conditions, helps to build effective social interactions and to find optimal ways of selfdevelopment, self-realization in difficult life circumstances (Leontev, Rasskazova, 2006). If stress tolerance means the ability to withstand various stressors, then psychological hardiness, as a life position, allows an individual to accept and understand events that cause fear and anxiety, rather than avoid them. Stress tolerance is a component of psychological hardiness that provides successful stress coping, mobilization of appropriate strategies and behaviors. As S. Maddi emphasizes, a person with high psychological hardiness is a person with a character, strong in spirit, not afraid of difficulties and problems. A resilient position allows a person to be aware of events that cause fear and anxiety and to accept rather than to avoid them. Psychological hardiness is a personal resource helping overcome constructively stress and restore an internal balance. The term "psychological hardiness" describes the ability to 
transform stressful circumstances, not to confront stress.

All the data obtained with Maddi's Personality Hardiness Scale (in the adaptation made by D. Leontev, O. Rasskazova) are within the norm, except for the "challenge" indicators of the women, which exceed the average values (Table $3)$. acterized by a resilient position that allows them to be aware of events that cause fear and anxiety and accept, rather than avoid, them. They are able to quickly build optimal coping strategies and use them productively.

In order to diagnose positive personal changes after extreme events, we used the Posttraumatic Growth Inventory of Tedeschi and Table 3.

The results of Maddi's Personality Hardiness Scale [compiled by the authors]

\begin{tabular}{|l|l|l|l|l|}
\hline $\begin{array}{l}\text { Scale } \\
\text { Group }\end{array}$ & $\begin{array}{l}\text { Commitment } \\
\text { (score) }\end{array}$ & Control (score) & Challenge (score) & $\begin{array}{l}\text { Total hardiness } \\
\text { (score) }\end{array}$ \\
\hline Men & 35.1 & 29.8 & 15.1 & 80.0 \\
\hline Women & 42.6 & 35.7 & 19.4 & 97.7 \\
\hline Total & 37.9 & 32.0 & 16.7 & 86.6 \\
\hline
\end{tabular}

There are no statistically significant gender differences, but we can see the tendency for significant differences for the commitment $\left(\mathrm{U}_{\mathrm{emp}}\right.$ $=43 \mathrm{U}_{\mathrm{Cr}}=38$ at $\mathrm{p} \leq 0.01$ and $\mathrm{U}_{\mathrm{Cr}}=51$ at $\left.\mathrm{p} \leq 0.05\right)$, challenge $\left(\mathrm{U}_{\mathrm{emp}}=40\right)$ and total hardiness $\left(\mathrm{U}_{\mathrm{emp}}=\right.$ 44). The obtained data are interesting, since D. Leontev and O. Rasskazova reported on the differences for different age groups, but not for genders or education levels (Leontev, Rasskazova, 2006).

Therefore, women more than men believe that the gained experience can support their development, are prone to assimilate actively this experience and use it further, tend to believe that what is happening gives them a real chance to find something important, interesting, enjoy their own activities.

Generally, the ATO combatants are char-

Calhoun in M. Magomed-Eminov's adaptation. The questionnaire is based on the assumption that life disasters cause not only negative reactions but also positive transformations for people experiencing them. These positive reactions are: changed attitudes towards others, new opportunities, increasing personal strength, spiritual changes, and the sense of life value. The generalized indicators of post-traumatic growth obtained with the Inventory (in the adaptation of M. MagomedEminov) do not exceed the average values (table 4).

The analyzed percentage distribution of the indicators (Table 5) shows that high scores for the "Appreciation of Life" scale have $48.1 \%$ of the examinees, about half of them show significant spiritual growth, and 55,8\% of the actual and demobilized military service members have a 
Table 4.

The data obtained with the Posttraumatic Growth Inventory of Tedeschi and Calhoun in M.

Magomed-Eminov's adaptation [compiled by the authors]

\begin{tabular}{|l|l|l|l|l|l|l|}
\hline \multicolumn{1}{|l|}{ Indicators } & $\begin{array}{l}\text { Relating to Others } \\
\text { (score) }\end{array}$ & $\begin{array}{l}\text { New Possibili- } \\
\text { ties (score) }\end{array}$ & $\begin{array}{l}\text { Personal } \\
\text { Strength } \\
\text { (score) }\end{array}$ & $\begin{array}{l}\text { Spiritual } \\
\text { Changes } \\
\text { (score) }\end{array}$ & $\begin{array}{l}\text { Appreciation of } \\
\text { Life } \\
\text { (score) }\end{array}$ & $\begin{array}{l}\text { Total } \\
\text { score }\end{array}$ \\
\hline Men & 16.1 & 13.6 & 11.7 & 4.8 & 8.6 & 54.5 \\
\hline Women & 24.1 & 18.4 & 17.7 & 4.9 & 12.0 & 77.1 \\
\hline Total & 18.3 & 15.1 & 13.4 & 4.7 & 9.6 & 61.0 \\
\hline
\end{tabular}

high total score.

Comparison of the ATO combatants-men and the ATO combatants-women shows that the average women's indicators "New Possibilities", "Personal Strength", "Spiritual Changes", sary changes, better understand that they can cope with difficult situations and perceive things as they are. They experience the growth of their own strength, better understand spiritual issues, they are more spiritual, more aware of the value of

Table 5.

The data obtained with the Posttraumatic Growth Inventory of Tedeschi and Calhoun in M. Magomed-Eminov's adaptation (percentage distribution) [compiled by the authors]

\begin{tabular}{|c|c|c|c|c|c|c|}
\hline $\begin{array}{ll} & \text { Level } \\
\text { Scale } & \end{array}$ & low & $\%$ & average & $\%$ & high & $\%$ \\
\hline Relating to Others & 9 & 33.3 & 10 & 37.0 & 8 & 29.7 \\
\hline New Possibilities & 4 & 14.8 & 11 & 40.7 & 12 & 44.4 \\
\hline Personal Strength & 4 & 14.8 & 11 & 40.7 & 12 & 44.7 \\
\hline Spiritual Changes & 7 & 25.9 & 13 & 48.1 & 7 & 25.9 \\
\hline Appreciation of Life & 7 & 25.9 & 7 & 25.9 & 13 & 48.1 \\
\hline Total score & 5 & 18.5 & 7 & 25.8 & 15 & 55.7 \\
\hline
\end{tabular}

"Appreciation of Life" are higher than that of men. Men's results do not go beyond average values. However, statistical differences were determined only to the indicator of "Personal Strength" $\left(\mathrm{U}_{\mathrm{emp}}=30 \mathrm{U}_{\mathrm{Cr}}=33\right.$ at $\mathrm{p} \leq 0.01$ and $\mathrm{U}_{\mathrm{Cr}}$ $=45$ at $\mathrm{p} \leq 0.05)$.

Women are more willing to make neces- their own lives and value each day.

The higher total score showed by women means that, after stress, they change their attitude towards other people towards greater openness, positivity and compassion. They have the feeling of new opportunities, new interests, desire for change, higher confidence in oneself, ability to 
overcome difficulties. They begin to understand other people's spiritual problems better.

Conclusions of the study and prospects for further research

The performed research show that the combat experience of the actual and demobilized military service members combines the effects of combat and non-combat stressors existing at war and stressors associated with being at the hostility zone, which leads to severe personal trauma, the appeared symptoms of post-traumatic stress disorder, a distinct tension of adaptation potential. The situation remains under control if combatant use the active problem- and emotionally-focused coping strategies, aimed at situation transformation, but not at a way out of the problem. Service members tend to use positive re-appraisal strategies, planning of problem solving, and selfcontrol; the joint action of these strategies is the positive way for social and psychological adaptation. The women-combatant (in comparison with men) choose more often "planful problem solving", "positive re-appraisal" and "seeking social support" strategies, the "self-controlling" copying is more important for men.

The effective means of combat stress control is psychological hardiness, as evidenced by the general psychological hardiness of the service members, focused on effective self-development.

Although combatants show distinct signs of maladaptation, half of them believe that their experience increases their value of life, support their spiritual and personal growth. Women show statistically significantly higher growth of personal strength. Therefore, post-traumatic growth goes hand in hand with attempts to adapt to a difficult situation.

The found features of rehabilitative resources characteristic for the actual and demobilized military service members are important for determination of the personal component of rehabilitative potential. The authors are planning to study further the impact of different psychotherapeutic methods, in particular psychodrama as a group technique, on the personal development of the military service members, and thus on the development of their rehabilitative potential. The authors are also planning to study the re-adaptive potential and mechanisms of the actual and demobilized military service members.

\section{References :}

Karayani, A. G. (2003). Psihologicheskaya reabilitaciya uchastnikov boevyh dejstvij [Psychological rehabilitation of the combatants]. Psihologicheskaya reabilitaciya uchastnikov boevyh dejstvij (80 p.). Moscow. URL: https://www.phantastike.com/ other/psikhologicheskaya_reabilitatsiya/pdf/

Karayani, A. G. (2014). Psihologicheskie posledstviya vojny i socialno-psihologicheskaya readaptaciya uchastnikov boevyh dejstvij [Psychological consequences and social-psychological readaptation of combatants]. Vestnik YuUrGU. Seriya Psihologiya, 7 (№ 4), C. 59-66. URL: https:/cyberleninka.ru/article/n/psihologicheskieposledstviya-voyny-i-sotsialno-psihologicheskaya- 
readaptatsiya-uchastnikov-boevyh-deystviy

Kisarchuk, Z. G., Omelchenko, Ya. M., Lazos, G. P., Litvinenko, L. I., Carenko, L. G. Psihologichna dopomoga postrazhdalim vnaslidok krizovih travmatichnih podij [Psychological assistance to victims of crisis traumatic events: a training manual] (2015). Psihologichna dopomoga postrazhdalim vnaslidok krizovih travmatichnih podij: metodichnij posibnik. Kyiv: Logos. URL: http://lib.iitta.gov.ua/706344/1/\%D0\%9F\%D0\% 9E\%D0\%A1\%D0\%86\%D0\%91\%D0\%9D\%D0\% 98\%D0\%9A\%20\%D0\%9F\%D1\%81\%D0\%B8\% D1\%85\%D0\%BE\%D0\%BB\%D0\%BE\%D0\%B3\% D1\%96\%D1\%87\%D0\%BD\%D0\%B0\%20\%D0\% B $\%$ D0\%BE $\%$ D0\%BF\%D0\%BE $\%$ D0\%BC $\%$ D0\%BE\%D0\%B3\%D0\%B0\%20\%20\%D0\%BF\% D0\%BE\%D1\%81\%D1\%82\%D1\%80\%D0\%B0\% D0\%B6\%D0\%B4\%D0\%B0\%D0\%BB\%D0\%B8\% D0\%BC\%2017_03_2015.pdf

Kokun, O., Agayev, N., Lozinska, N. (2018). Viznachennya stresogennih chinnikiv bojovoyi diyalnosti, sho zumovlyuyut viniknennya u vijskovosluzhbovciv PTSR [Identification of combat stress factors that impect military service member's PTSR in]. Psihosocialna pidtrimka osib $z$ travmoyu vijni: mizhnarodnij dosvid ta ukrayinski realiyi: zbirnik materialiv, dopovidej Vseukrayinskoyi naukovopraktichnoyi konferenciyi, m. Mariupol, 28 lyutogo 2018 r., P. 36-38.

Koshova, I. V., Vinnicka, T. G. (2009). Osoblivosti vikoristannya koping-strategij pri ovolodinni pozitivnimi ta negativnimi stresovimi situaciyami [The features of coping strategy use at control over positive and negative stress situations]. Aktualni problemi psihologiyi: Psihologiya osobistosti. Psihologichna dopomoga osobistosti, volume 11 (issue 2), P. 92-98.

Kryukova, T. L., Kuftyak, E. V. (2007). Oprosnik sposobov sovladaniya (adaptaciya metodiki WCQ)
[Questionnaire of coping methods (adaptation of the Ways of Coping Questionnaire)]. Zhurnal prakticheskogo psihologa, № 3, P. 93-112. URL: https://forpsy.ru/methodology/ trudnye_zhiznennye_situatsii/ oprsonik_sposobov_sovladaniya_s_tzhs_adaptatsiya_metodiki_wcq-_/

Leontev, D. A., Rasskazova, E. I. (2006). Test zhiznestojkosti [Psychological hardiness test]. Moscow: Smysl. URL: http://www.aksp.ru/work/ activity/nac_strateg/resurs_centr/files/ soln_testgizn.pdf

Magomed-Eminov, M. Sh. (2009). Fenomen posttravmaticheskogo rosta. [The phenomenon of post-traumatic growth]. Vestnik $T G U$, issue 3 (71), P. 111-117. URL: http://cyberleninka.ru/article/n/ fenomen-posttravmaticheskogo-rosta.pdf

Maksimenko, S. D., Prokofieva, O. O., Tsarkova, O. V., Cehmister Ya. ., Kochkurova O. V. (2015). Praktikum iz grupovoyi psihokorekciyi [Group psychological correction: Practical guide] (issue 2). Kyiv: Slovo. URL: http://eprints.mdpu.org.ua/ id/eprint/6958/

Reshetnikov, M. M., Chermyanin, S. V., Korzunin, V. A. (2005). Adaptaciya i readaptaciya kak socialnopsihologicheskaya problema [Adaptation and readaptation as a social-and-psychological problem]. Filosofskie nauki, № 10, P. 31-44.

Shamrei, V. K. (2015). Psihiatriya vojn i katastrof [Psychiatry of wars and disasters]. SanktPeterburg: SpecLit. URL: https:// psy.wikireading.ru/76668

Snedkov, E. V. (1997). Boevaya psihicheskaya travma: (kliniko-patogeneticheskaya dinamika, diagnostika, lechebno-reabilitacionnye principy) [Combat psychic trauma: clinical and pathogenetic dynamics, treatment and rehabilitation principles]. (dissertation abstract, Voenno-medicinskaya 
akademiya) [Military-Medical Academy]. URL: http://medical-diss.com/medicina/boevayapsihicheskaya-travma-kliniko-patogeneticheskayadinamika-diagnostika-lechebno-reabilitatsionnyeprintsipy

Syropyatov, O. G. (2013). Mediko-psihologicheskoe soprovozhdenie specialnyh operacij [Medical and psychological support for special operations]. Moscow: Litres. URL: https://www.ereading.club/bookreader.php/1017817/

Syropyatov_-

_Mediko_psihologicheskoe_soprovozhdenie_speci alnyh_operaciy.html

Tarabrina, N. V., Agarkov, V. A., Byhovec, Yu. V. etc. (2007). Prakticheskoe rukovodstvo po psihologii posttravmaticheskogo stressa [Practical guide to the psychology of post-traumatic stress]. Moscow: Kogito-Centr.

Tedeschi, R. G., Calhoun, L. G. (2004). Posttraumatic Growth: Conceptual Foundations and Empirical Evidence. Psychological Inquiry, № 15 (1), P. 118. DOI: $10.1207 / \mathrm{s} 15327965$ pli1501_01

Titarenko, T. M., Larina, T. O. (2009). Zhittyestijkist osobistosti: Socialna neobhidnist ta bezpeka [The personal resilience: social need and security]. Kyiv: Marich. URL: http://lib.iitta.gov.ua/9065/1/ Zhiznestoykost_lichnosti.pdf

Vasserman, L. I. (2009). Metodika dlya psihologicheskoj diagnostiki sposobov sovladaniya so stressovymi i problemnymi dlya lichnosti situaciyami. Posobie dlya vrachej i medicinskih psihologov [The methodology for the psychological diagnostics of coping with stressful and problematic situations. Manual for doctors and medical psychologists]. URL: http://www.medpsy.ru/library/library142.pdf

Vodopyanova, N. E. (2009). Psihodiagnostika stressa [Psychodiagnosis of stress]. Sankt-Peterburg: Piter. URL: https://www.phantastike.com/stress/ psych_stress/pdf

Zajceva, Yu., Prokofieva, O., Prokofieva, O. (2017). Komponenti gromadyanskoyi identichnosti ta osoblivosti yih rozvitku [Components of civic identity and peculiarities of its development]. Psychological Journal: Scientific Review of H.S. Kostyuk Institute of Psychology, National Academy of Educational Sciences of Ukraine, № 5 (9), P. 58-69. DOI: 10.31108/1.2017.5.9.5

\section{Олеся Прокофьева}

Кандидат психологических наук, доцент, доцент кафедры психологии, Мелитопольский государственный педагогический университет имени Богдана Хмельниикого, г. Мелитополь (Украина)

\section{Инна Викторовна Кочова}

Кандидат психологических наук, доиент, доиент кафедрь общей и прикладной психологии, Нежинский государственный университет им. Николая Гоголя, г. Нежин (Украина)

\section{Ольга Анатольевна Прокофьева}

Стариий преподаватель кафедры анатомии и физиологии человека и животных, Мелитопольский государственный педагогический университет имени Богдана Хмельницкого, г. Мелитополь (Украина)

\section{ОСОБЕННОСТИ ЛИЧНОСТНЫХ РЕАБИЛИТАЦИОННЫХ РЕСУРСОВ ВОЕННОСЛУЖАЩИХ И ДЕМОБИЛИЗИРОВАННЫХ}

\section{АННОТАЦИЯ}

Боевая деятельность - сильная психотравмирующая ситуация, в которой действуют профессиональные, ситуационнопсихогенные, личностные (прямые и косвенные) стресс-факторы. В экстремальных условиях боевой стресс выполняет адаптационные функции, но длительные и неблагоприятные воздействия, превышающие индивидуальный 
адаптационный потенциал (психологический ресурс), психологически травмируют, приводя к боевой психологической травме и дальнейшей дезадаптации. Отреагирование травматического события может происходить как без признаков нарушения адаптации, так и проявляться как патологическая психическая дезадаптация и адаптационные расстройства.

Процессы социальной и психологической адаптации личности после боевой деятельности при наличии внутренних (личностных) и внешних (социальных) ресурсов, могут протекать без существенных психопатологических нарушений. Существует возможность и глубокой личностной трансформации - «постравматического роста», что происходит параллельно попыткам приспособиться к сложным жизненным обстоятельствам.

Высокая степень психотравматизации военнослужащих и демобилизованных обуславливает остроту проблемы психологической и социальной помощи людям, которые принимают (принимали) участие в боевых действиях, одной из форм которой является реабилитация.

Тенденциями становления системы социальной и психологической реабилитации участников боевых действий является ориентация на использование реабилитационных ресурсов общества и личности, сочетание традиционных психологических мероприятий и опосредованных форм психологической и социальной помощи. Успешность реабилитации, показателями которой являются противодействие стрессу, восстановление функционального состояния, личностная самореализация, во многом зависят от реабилитационных ресурсов личности, их эффективного использования. Ресурсы овладения стрессовыми ситуациями описывают понятия «жизнестойкость», «адаптационные возможности», «сопротивляемость стрессу» и другие.

Установлено, что боевой опыт военных и демобилизованных сочетает влияние боевых и небоевых стрессоров, приводит к выраженному травмированию личности, появлению симптомов посттравматического стрессового расстройства, выраженному напряжению адаптационного потенциала. Овладение ситуацией происходит благодаря использованию активных проблемно- и эмоциональносфокусированных копинг-стратегий преобразования ситуации, а не выхода из нее.

Участники боевых действий склонны использовать стратегии переоценки, планировать решение проблемы и реагировать повышением самоконтроля. Сочетание этих стратегий показывает положительный характер процесса социально-психологической адаптации. Установлены гендерные различия. Тенденция использовать копинги «планирование решения проблемы», «переоценка ситуации» и «поиск социальной поддержки» больше выражена у женщин-военных, для мужчин характерно повышенное значение копинга «самоконтроль». 
Жизнестойкость является важной составляющей личностного реабилитационного потенциала, что подтверждается общей позицией жизнестойкости испытуемых, ориентированной на эффективное саморазвитие. Участники боевых действий в целом проявляют выраженные признаки дезадаптации, но половина из них оценивают свой опыт как такой, что повысил ценность их жизни, вызвал духовный рост, они проявляют общую тенденцию личностного роста, причем группа женщин-военнослужащих достоверно превышает группу мужчин по показателям роста силы личности. Можно констатировать, что посттравматический рост идет параллельно с попытками приспособления к трудной ситуации.

Ключевые слова: боевой стресс, боевая психологическая травма, посттравматический рост, копинг-стратегии, жизнестойкость, реабилитационные ресурсы личности, военнослужащие, демобилизованные военнослужащие, ветераны.

\section{Олеся Прокофьева}

Кандидат психологічних наук, дочент, дочент кафедри психологї̈, Мелітопольський державний педагогічний університет імені Богдана Хмельницького, г. Мелітополь (Украӥна)

\section{Інна Вікторівна Кочова}

Кандидат психологічних наук, дочент, дочент кафедри загальної та придатної психології, Ніжинський державний університет ім. Николая Гоголя, г. Ніжин (Україна)

\section{Ольга Анатольевна Прокофьева}

Стариий підготовитель кафедри анатомії та фізикології людини та тварин, Мелітопольський державний педагогічний університет імені Богдана Хмельницького, г. Мелітополь (Україна)

\section{ОСОБЛИВОСТІ ОСОБИСТІСНИХ РЕАБІЛІТАЦЙНИХ РЕСУРСІВ ВІЙСЬКОВОСЛУЖБОВЦІВ ТА ДЕМОБІЛІЗОВАНИХ}

\section{АНОТАЦІЯ}

Бойова діяльність - сильна психотравмуюча ситуація, в якій діють професійні, ситуаційно-психогенні, особистісні (прямі і непрямі) стрес-фактори. В екстремальних умовах бойової стрес виконує адаптаційні функції, але тривалий і несприятливий вплив, що перевищує індивідуальний адаптаційний потенціал (психологічний ресурс), психологічно травмують, призводячи до бойової психологічної травми і подальшої дезадаптації. Відреагування травматичної події може відбуватися як без ознак порушення адаптації, так і виявлятися патологічною психічною дезадаптацією і адаптаційними розладами.

Процеси соціальної та психологічної адаптації особистості після бойової діяльності при наявності внутрішніх (особистісних) і зовнішніх (соціальних) ресурсів, можуть протікати без істотних психопатологічних порушень. Існує можливість і глибокої особистісної трансформації - «постравматичного зростання», що відбувається паралельно спробам пристосуватися до складних життєвих обставин. 
Високий ступінь психотравматизації військовослужбовців і демобілізованих обумовлює гостроту проблеми психологічної та соціальної допомоги людям, які приймають (брали) участь у бойових діях, однією з форм якої є реабілітація.

Тенденціями становлення системи соціальної і психологічної реабілітації учасників бойових дій є орієнтація на використання реабілітаційних ресурсів суспільства і особистості, поєднання традиційних психологічних заходів і опосередкованих форм психологічної і соціальної допомоги. Успішність реабілітації, показниками якої є протидія стресу, відновлення функціонального стану, особистісна самореалізація, багато в чому залежить від реабілітаційних ресурсів особистості, їх ефективного використання. Ресурси оволодіння стресовими ситуаціями описують поняття «життєстійкість», «адаптаційні можливості», «опірність стресу» та інші.

Встановлено, що бойовий досвід військових та демобілізованих призводить до вираженого травмування особистості, появи симптомів посттравматичного стресового розладу, вираженого напруження адаптаційного потенціалу. Оволодіння ситуацією відбувається завдяки використанню активних проблемно- та емоційно-сфокусованих копінг-стратегій перетворення ситуації, а не виходу з неї. Учасники бойових дій схильні використовувати стратегії переоцінки, планувати вирішення проблеми і реагувати підвищенням самоконт- ролю. Поєднання цих стратегій показує позитивний характер процесу соціальнопсихологічної адаптації. Виявлено ряд гендерних відмінностей у використанні копінгів. Тенденція використовувати копінг «планування вирішення проблеми», «переоцінка ситуації» $\mathrm{i}$ «пошук соціальної підтримки» більше виражена у жінок-військових, для чоловіків характерно підвищене значення копінга «самоконтроль».

Життєстійкість є важливою складовою особистісного реабілітаційного потенціалу, що підтверджується спільною позицією життєстійкості випробовуваних, орієнтованої на ефективний саморозвиток. Учасники бойових дій в цілому проявляють виражені ознаки дезадаптації, але половина 3 них оцінюють свій досвід як такий, що підвищив цінність їх життя, викликав духовне зростання, вони виявляють загальну тенденцію особистісного зростання, причому група жіноквійськовослужбовців достовірно перевищує групу чоловіків за показниками зростання сили особистості. Можна констатувати, що посттравматичне зростання йде паралельно зі спробами пристосування до важкої ситуації.

Ключові слова: бойовий стрес, бойова психологічна травма, посттравматичне зростання, копінг-стратегії, життєстійкість, реабілітаційні ресурси особистості, військовослужбовці, демобілізовані військовослужбовці, ветерани.

\section{Дата отримання статті: 21.09.2019 Дата рекомендації до друку: 11.10.2019 Дата оприлюднення: 31.10.2019} (C) Olesia Prokofieva, Inna Koshova, Olga Prokofieva 